\title{
Resources and Exchange in the Northern Part of the Republic of Sakha (Yakutia)
}

\author{
Nikolai S. Goncharov* \\ Peter the Great Museum of Anthropology \\ and Ethnography (Kunstkamera) RAS \\ 3 University emb., St. Petersburg, 199034, Russia
}

Received 02.03.2019, received in revised form 30.07.2019, accepted 09.08.2019

The article discusses the parameters of the exchange of resources in a settlement on the Lena river in the Northern part of Yakutia. The main purpose of the work is to clarify the phenomenon of exchange through the study of peculiarities of building up the socio-cultural space through exchange practices. The subject of research is the phenomenon of exchange localized in a specific context of its functioning. The work is based on materials collected by the author during the fieldwork carried out in 2018. The first part of the article identifies the research problem, briefly describes the main theoretical developments that were used in the article or influenced the character of the author's reflection on this material. Further there is a description of the socio-cultural components that form the exchange practices; "dispersion" of the general context of the settlement into separate groups of elements combined (only potentially) by a functional connection with the phenomenon of exchange. Examples of "contexts" made up of these elements and various ligaments reflecting them are also considered in the article: in the sphere of harvesting, trade, feeding of spirits, national holidays, etc. In the final part, the author formulates main views and conclusions about the problem under study: the socio-cultural field of exchanges is a continuum of relations, material (living and non-living) objects, their behaviour, properties, etc., which requires a special "tool" to work with it. According to the author, such "tools" are the concepts of "thickening", "compaction", "unleashing”, etc., because in the continuous field of exchange relations they allow fixing the centres of "thickening" of certain parameters indicating the specificity of the exchange procedures. The author makes a conclusion about the "out-of-culture", actual property of the act of communication in the form of exchange, and indicates its binding potential. Through a structural analysis of the exchange in general, it was concluded that the resource asymmetry provokes the exchange; the definition of exchange was given. The findings can be applied to the analysis of energy flows in a sociocultural environment.

(c) Siberian Federal University. All rights reserved

* Corresponding author E-mail address: nikola.gon4arov@yandex.ru

This work is licensed under a Creative Commons Attribution-NonCommercial 4.0 International License (CC BY-NC 4.0). 
Keywords: exchange, socio-cultural space, thickening, fishing, crafts, context, trade, continuum, attractiveness.

The work was supported by the RSF project "Energy of the Arctic and Siberia: The Use of Resources in the Context of Socio-Economic and Environmental Changes" (No. 18-18-00309).

Research area: ethnography, ethnology and anthropology.

Citation: Goncharov, N.S. (2019). Resources and exchange in the Northern part of the Republic of Sakha (Yakutia). J. Sib. Fed. Univ. Humanit. soc. sci., 12(8), 1425-1441. DOI: $10.17516 / 1997-1370-0458$.

'The terms 'offering', 'a present, 'a gift' that we used are not very precise by themselves. We just did not manage to find others, that's all"

Mauss M. The gift. Societies. Exchange. Personality. Works on social anthropology.

M., 2014. P. 272

\section{Introduction and theoretical basis}

In this article we will discuss exchange practices in a settlement located on the Lena River, beyond the Arctic Circle. The name of the settlement was changed to Prilensky, since some field examples presented in the article reflect the interaction of local residents with the author not through the lens of informants-ethnographer, but in a personal form; also certain aspects of the economic sphere and social practices have an uncertain legal status and lie in the sphere of informal nature management.

The exchange of resources that we understand broadly (material, symbolic, other resources) is an inherent feature of any society. Turning to the analysis of exchange practices, in our opinion, the researcher is faced with a global socio-cultural parameter (function, trait, etc.) of distribution and sequencing, where the phenomena of exchange that we are considering are just a particular case (from the point of view of the distribution form) (Chesnov, 2001: 138).

Many researchers addressed questions we are interested in; we will focus only on some of the publications that were used in the process of writing this article. I would like to mention the work of M. Mauss "The Gift" (Mauss, 2014), in which the author deals with the problem of exchange, offering, in terms of the phenomenon of the disinterested transfer of various objects. It is important to point out that the exchange practices and conditions that shape them are "a huge complex of facts, each of which is very complex by itself. Here, everything that actually constitutes a social life of 
the societies that preceded ours, including the proto-historical society, is jumbled" (Mauss, 2014: 137). This statement is valuable for us because it reflects the complexity of the characteristics arising from the exchange. It was also reflected in the work of M. Sahlins "Stone Age Economics", where he wrote: "The actual kinds of reciprocity are many in any primitive society, let alone in the primitive world taken as a whole. "Vice-versa movements" may include sharing and counter-sharing of unprocessed food, informal hospitality, ceremonious affinal exchanges, loaning and repaying, compensation of specialized or ceremonial services, the transfer that seals a peace agreement, impersonal haggle, and so on and on (Sahlins, 1999). What is also important is the very concept of "reciprocity" introduced by B. Malinowski (Malinowski, 2004) and considered by the founder of substantivism (direction in economic anthropology, characterized by consideration of economic processes through the prism of a particular culture), K. Polani, as one of the main forms of integration of the economy of primitive society (Socio-Economic Relations and Socio-Formative Culture, 1986: 178). However, as noted in some referenced publications, "there is no clear definition of reciprocity in the literature" (Socio-Economic Relations and Socio-Formative Culture, 1986: 178), which makes work difficult. But still, according to M. Sahlins (the most common understanding), reciprocation should be understood as the continuum of exchange procedures, and the exchange itself refers to the "producers' relation to the productive process" (Sahlins, 1999). As the author wrote, "It is not merely "production for use" but production for use value, even though the acts of exchange, and as opposed to the quest for exchange value" (Sahlins, 1999). The latter, however, again introduces some uncertainty, because commodity relations are excluded from the sphere of "exchange".

The position of N. V. Ssorin-Chaikov is closer to our point of view. In the article "Bear skins and macaroni..." he understands the exchange extensively, involving a gift, tribute, barter and trade in it (Ssorin-Chaikov, 2012: 61). The author focuses on the exchange of material values and their accompanying meanings (Ssorin-Chaikov, 2012: 67). We are also interested in the exchange in a broader interpretation.

Further, the research is focused not so much on the economic side of exchange, but on exchange as a parameter of building social and cultural ties and as a property of the sociocultural environment in which resources circulate. The exchange of objectified energy is considered as linking various social and cultural components of the function.

There is a number of concepts that allow analysing social space. Among modern publications one should mention the book by I. Morris "Foragers, Farmers and Fossil Fuels", where the author deduces the consistent dependence of social values on 
social organization, which is related to the population and, mainly, everything is tied to the method of extracting energy from resources (Morris, 2017). Such a position in our case seems too general and reflects more global trends. What is much closer to us is the understanding of social space by Pierre Bourdieu, whose work builds a multidimensional model related to the distribution (social, cultural, symbolic) of capitals among the agents forming classes and seeking to impose, legitimize their vision of the world, etc. (Bourdieu, 2017: 16-17, 21). The first part, which describes the space from the point of view of the multidimensionality of the interweaving of various components, is more relevant to the collected material, if we take into account the "capital-resources" ligament.

\section{Components of the exchange}

Prilensky settlement was founded by Russian explorers in the $17^{\text {th }}$ century in the territory of residence of Evenkis and Yakuts. Currently it is a fairly large and lively settlement with about three and a half thousand people. Evenkis and Yakuts predominate in the ethnic composition of the population, then there are Russians, Evens, Ukrainians, Armenians and representatives of some other groups. Despite the very long distance from the urban environment, the settlement has a social infrastructure, the supply of necessary resources (in summer - by water and by air, in winter - by airplane and winter road), there are kindergartens, a diesel power station, a boiler station, Ministry of Emergency Situations, a large modern hospital, a children's art school and other institutions. With the help of numerous creative teams and clubs, an ethnocultural component is reproduced and used, which is clearly manifested during the days of arrival of foreign tourists. Local cultural figures modify the social and cultural environment, introducing new holidays into Prilensky's life (for example, the spring Evenki holiday Bakaldyn or Lena's Day), as well as supporting conventional practices (mass celebration of Ysyakh).

Prilensky is located in a place where the flora and fauna generously endow the population of the settlement. Most men, regardless of ethnicity, are engaged in hunting and fishing. Women and children gather berries (blueberries are in great demand). Reindeer herding, fishing, hunting for fur-bearing animals are the traditional types of economic activity.

However, although the settlement has a strong and developed infrastructure, it still largely depends on resources supplied from other areas. Therefore, based on the production and focus on exchange practices that form resource flows, we can distinguish 
two main lines: an internal line linked to the exchange in the territory of Prilensky and the region (which is thought not exactly as a main line, but as an interlaced tangle); and an external line associated with resources coming from outside (mainly from Yakutsk, but not only). There are also two sources of resources:

1) harvesting, folk crafts, administration, cultural (in administrative sense) and medical institutions, gas station, hospital, river port, etc. - associated with the first direction;

2) harvesting, folk crafts, administration, cultural and medical institutions and other local sources; as well as numerous external sources related to the production and sale of equipment, food products, construction materials, political, administrative resources, etc. - associated with the second direction.

As can be seen, in the first and second lists there are a lot of intercrossing elements, which indicates the interrelation of the internal and external directions of exchange. Of course, the lists can be greatly expanded, but we do not set ourselves the task of describing all the sources of resources that form the specificity of exchange in Prilensky; what is more important for us is the structural projection of the exchange and features of the connections of the components that form the phenomenon of exchange.

Agents of the exchange practices are local people, nature (in general), animals, official institutions (school, hospital, state), business structures (private entrepreneurs, companies), infrastructure facilities, cultural objects (museum, cultural centre), tourists, ethnographers, etc. The list can be continued: if we proceed from the actornetwork theory (Latour, 2014), the objects of a completely different nature can act as units of social relations. We adhere to the same logic with respect to the objects of exchange, which we interpret widely: from a fish to behavioural actions that, for example, can express ethical norms reflecting, in turn, a favourable/negative attitude toward people, gratitude for material benefits.

In addition to the elements themselves, the unconditional value is represented by channels and other conditions that form their (elements') circulation. We refer to direct channels (here, as an admission, we also include hunting, fishing, etc. as channels of exchange with the natural environment), indirect contacts (shops, Internet, post office, hospital, port, etc. (the peculiarity of the last two is that, being the producers of the objects of exchange, at the same time, they are the places-channels through which the data on resources are obtained, that is, the localization of exchange)). By "other conditions" that determine the circulation of elements (exchange), we understand, for 
example, a range of "formal/informal practices", "legal/illegal activities", etc., which, of course, is of great importance for establishing procedures under study.

Based on the above, it can be stated that we have a free set of elements united by the desire of the researcher, and the main limitation in its creation was a functional connection with the phenomenon of exchange in the settlement of Prilensky. With such structural dispersion of elements (agents, objects, sources, etc.), the following question arises: what is the limit of atomization of the phenomena associated with the exchange, and how does their unification into integral socio-cultural phenomena occur? A significant role here is played by performativity considered by N. V. Ssorin-Chaikov on the anthropological material, when a socio-cultural phenomenon exists, because it is allocated by a man in a specific modality. The difficulty for the researcher is to interpret the nature of allocation: whether a certain exchange act is intentional or is carried out unconsciously; represents value by itself or is embedded in a wider context, etc. The sets of elements and methods of their exchange are the derivatives from the activities of the local residents of Prilensky and places with which they interact. Thus, we should consider specific combinations of mentioned (and other) components that identify the exchange operations.

\section{"Natural" combination of elements}

Exchange as a socio-cultural phenomenon is not dependent on other parameters of the environment, it is closely intertwined with it. One of the main factors associated with the scope of ideas, continuity, etc. is an ethnohistorical factor that determines the general context characteristic of a representative of a certain ethnic group. In this case, we are talking about Evenki custom of mutual aid, expressed, in particular, in a gift, Nimat (Sirina, 2011). My informants (both Yakuts and Evenkis) repeatedly (with respect/pride) said that Evenkis have a national trait, which is manifested in their willingness to share prey when hunting or fishing, to share berries, etc. As one of my informants, V.S., said: "Evenkis had a good custom — they did not sell anything, but they gave everything to their relatives (and not only). Her husband's father [Evenki] did not leave anything for himself except for food. Yakuts, on the contrary, left products for tomorrow..." "Evenkis have never been tight-fisted, they survived thanks to this."

Another informant, an elderly Evenki E.K., also repeatedly emphasized that Evenkis always had a custom to help others through giving away the results of fishing, hunting, gathering, etc. She herself always shares, for example, blueberries or other resources with relatives and acquaintances. Her grandson - V.T. told me that he 
adheres to the same behavioural stereotypes determined by ethnic tradition. In the next conversation, to my question about whether he helps his relatives with some resources, V.T. replied that he sometimes supplies his sisters with fish (not siblings, but cousins or more distant ones in the structure of kinship), and for that they will help him in the future (with repair works).

I should note that the author of the article himself got into this system of "generalized reciprocity". Almost every day I was supplied with food (frozen fish, venison), was often invited to the table, treated with fish, meat dishes, blueberries and other food. In general, during the expedition, members of this family provided me with great assistance in finding informants, moving around the settlement and visiting the surroundings. I stayed at a V.T. parents' apartment, and when the time to pay for the accommodation came, they did not take money from me, saying that "we must help people like you (bearing in mind my ethnographer's identity)."

It is also interesting how the ethnocultural specificity determines the attitude to the resources themselves that have to be exchanged. For the local Evenkis and Yakuts, hunting and fishing objects are important components of their emotional and, often, economic life. Animal husbandry (we do not consider reindeer herding) and horticulture, which were very successfully developed during the USSR period, after 1991 have totally degraded (only two families keep cattle in the whole settlement). But from conversations with informants, among which Evenkis and Yakuts prevailed, I could understand that such a situation did not bother them too much. Often, the locals stressed that "on this land, it is impossible to properly engage in horticulture," "nothing grows here," and there is no necessary food supply for the cattle. A completely different attitude was expressed by N.N. who defined himself as a Ukrainian. He spoke extremely reproachfully about the indigenous population, in the sense that they did not want to engage in agriculture. It is much easier for them to shoot game or to catch a fish. N.N. thinks that "it is appropriate to show heroism that you killed a beast or caught a fish," because "one thing is that you raised it and killed, and the other thing is that you just came to the forest and shot it. Just like that. In such a way they may kill everything." N.N. told me that at the end of the Soviet period, agriculture in Prilensky underwent major flourishing: cows were transported on barges to the islands where they grazed on, people began to build greenhouses, pigsties (up to 550 pigs only on the aviators farm, the state farm had 90 heads) chicken coops, etc., - there were eggs, pork; people actively purchased compound animal feedstuff, etc. At present, N.N. has two greenhouses where potatoes, cabbage, 
tomatoes grow, etc. Such material allows us to speak about the existing ethnocultural stereotypes of economic activity.

Above we have repeatedly mentioned fish resources. Indeed, fish is one of the key food resources in Prilensky. Such valuable varieties of fish as sturgeon, nelma, taimen, etc. can be found here. Fishery is a set of elements related to the preparation for the process, the process itself and the further use of fish. Preparation for fishing includes: acquisition of suitable gear, clothing, boat preparation, determination of a place (as a rule, these places are limited), cooperation with other fishermen, arrangements for a possible sale, etc. "We, fishermen, mainly catch fish with a net," my informant, V.T., said. Once caught, fish is either frozen in freezers for personal consumption or is sold through established channels (someone sells to passing ships, others go to sell fish in Yakutsk; there are many other strategies). The Internet entered and began to be actively used in the fishing industry. So, some Prilensky fishermen order tackles through it (for example, from St. Petersburg); use the instant messaging system "WhatsApp", where there are thematic communities of fishermen and hunters, sharing tips on the process of hunting/fishing, improving equipment, etc. When fishermen go by boat along the rivers towards the Verkhoyansk Range, those who can afford and feel the need for this, use satellite phones.

The Internet is also a means of selling products of labour. One of my informants A. Kh. is known for his skill in making knives not only in Prilensky, but throughout Yakutia, since he is a participant and a winner of regional and republican exhibitions. On the Internet A. Kh. looks for the information he needs in smith craft, setting up a smith shop, consults masters from other districts and cities, and orders professional materials. Also, he and his friend use the Internet, in particular YouTube, to advertise their products and their sales. Offers come from different cities of Russia, including the European part. The local population also reaches out to A. Kh. in order to repair or modify snow tractors, motorcycles, etc.

In addition to these "specific" exchange relations, local residents also encourage exchange with creatures of non-human nature - "spirits", who in the considered cases acted as patrons of nature and, in particular, animals. To illustrate the exchange practices with Baianai - the spirit of forests, animals and patron of hunters, we may give an example of a fishing trip near the settlement on the banks of the Lena. There were three participants: V.T., his colleague S. and me. On the way, we stopped by a store, bought cigarettes, tea, and some other products; having arrived on shore, we began to unravel a net. In Prilensky there is a compulsory custom for leaving coins/cigarettes or other 
items for a river. Until the day we are describing, V.T. went fishing several times, and each time left a "gift" (?) to the river. When V. T. first asked me if I had a coin in order to "feed the river," I took it as a joke. However, V.T. made an objection, stressing the importance and necessity of this practice. Other informants also confirmed that fire or river "need to be fed." As I could understand, "feeding" does not occur immediately, but during the fishing process; V.T. carefully put a cigarette on the beach, but I threw coins into the water first, but then I also began to behave more carefully and put coins on the beach. V.T. recalled that I needed to "feed the river" each time when I got lucky with a bite. After several trips to the Lena, V.T. remarked that we had never lit a fire, and this, as he put it, was not very good. Therefore, returning to the events with the unravelled net, when the net was finally unravelled, and the fire was organized, V.T., taking a glass of cognac (S. and I also took the glasses), told me that I should turn to Baianai, because I am a "new person". As I can judge, the words I chose were not quite correct, because after me V.T. turned again to the fire and after a few seconds we threw out the contents of our glasses into the fire.

Unfortunately, that evening we did not catch anything, but we found a mammoth tusk on the shore. It was quite long (about $60 \mathrm{~cm}$ ) and weighed about 5-7 kg, but the bone had significant damage. For some time, my comrades could not believe that it was really a tusk, because such a finding on the shore near the settlement was the first of its kind, but gradually the doubts disappeared. V.T. called his brother to share the news and find out how to proceed. As a result, they decided to generously "feed the fire" at first, they threw a few tea bags into it, then put a sandwich on the bonfire and spilled cognac. This finding had a strong emotional impact on V.T.

Regarding the "feeding of fire" ritual, I would like to note that if it is impossible to "feed" the fire directly, a stove burner can become its substitute, around which certain words are also pronounced, and after that the contents of the container held in hands is splashed onto the red-hot surface.

The Yakut folk holiday Ysyakh can also be an example of the exchange of cultural and symbolic capital/resources. "According to the memories of veterans of culture, in Prilensky people have been celebrating the Ysyakh festival since 1967 as a holiday of rebirth of Nature and Man." In the Soviet period, from the national Yakut holiday it transformed into a nationwide event. For its celebration, a special platform is set up next to Prilensky, where a stage, benches, serge, urasas and a low farce are installed. The presence of several groups of urasas indicates the social structure of this festival, because it involves various professional/territorial (from other naslegs) groups that 
develop a separate site for themselves. On the day of the holiday, various competitions are held. They are associated with demonstration of national clothes, cooking traditional dishes, finding winners, as well as the sports and concert part with evening (and night) presence on this site (outdoors or in urases). All residents of the settlement and neighbouring naslegs, regardless of ethnicity, take part in the festival. In the course of implementation of this practice, formation (even during preparation, when costumes are sewed, the site is prepared, a program is thought out, etc.), translation and perception of ethnocultural stereotypes take place, as well as bedding of different cultural layers, with varying degrees of "authenticity" and attractiveness, but what is the most important here is the culturally shaped social unification, and actions about the implementation and exchange of these stereotypes.

Thus, in the third part of the article we examined the sociocultural phenomena that give rise to and depend on exchange; showed how flows uniting people, objects of material culture, symbols, knowledge, natural space, etc. are formed (Urry, 2000: 36). Attention is focused on such aspects as the exchange with different agents (people, nature, Baianai), junction of exchanges and processes accompanying fishing activity; aspects of the exchange in the socio-symbolic context (Ysyakh) are reflected; the value of the ethno-cultural diachronic parameter is demonstrated through "nimat", the role of the latter is also reflected through its ability to influence the resource concept itself.

\section{Theoretical conclusions}

The reduction and fragmentation of the exchange process into components from the perspective of an outside observer can be carried out extremely arbitrarily, because the "assemblies" of the integrity, in this case, are performed by the actors of the exchange, consciously or not. Elements and their assemblages are in a single field of existence, united by the life-sustaining activity of the population of the settlement (third part of the article). It is quite difficult to navigate in this field, taking into account the exchange, allocation of resources and capital. Speaking about the social and cultural phenomenon of Prilensky, we can single out a common flow, a scattered set of elements and "look" (a look - a certain assembly of elements) at it from different sides: from the point of view of the elements themselves, and from the point of view of the formation of contexts. It is worth pointing out the phrase of Iu. V. Knorozov that "the system is an area of increased communication" (Knorozov, 1973: 1); This sets a direction of the look, a search for some areas of the increased communication, "sealing" (for a certain reason). The theme of "sealing"/"thickening" was developed 
in the works of various researchers. For example, Edmund Leach, in his book "Culture and Communication..." wrote that these "thickenings" lead to a joint experience of communicative experience "simultaneously through many different sensory channels; they act in accordance with an orderly sequence of metaphorical events within the territorial space, which itself was arranged in such a way as to provide a metaphorical context for this playing action [italics added - N.G.]... When we participate in... a ritual, we receive all these messages [verbal, visual-aesthetic, etc. - N.G.] at the same time, "thickening" them in a single experience, which is described as "attending a wedding..." etc. But the researcher is forced to take each dimension, and moreover do it separately, and then it turns out that it is almost impossible to give a really convincing explanation of how different dimensions are connected together to implement a single common message" (Leach, 2001: 53).

In the works written by E. Leach, the concept of "thickening" is a way of describing and analysing the sociocultural environment (very painless for it). The work in the same direction was carried out by other researchers as well; for example, M. Callon wrote: "Talking about the performativity of the economy means the assumption that agency is distributed," and "action is a collective phenomenon that is naturally overcrowded" (Callon, 2005: 3, 4; quoted by Ssorin-Chaikov, 2012: 69). Metaphors of "thickening", "overcrowding", "entwining", "unwinding" (SsorinChaikov, 2012: 69), etc. can be attributed to a single analytical style, which involves considering the object/studied part of reality from the point of view of its (smooth) morphology. "Complexes of densities" appear, and they are expressed, for example, by ethnic aspects: history (a diachronic parameter) or historical results are "packed" into ethnic stereotypes (nimat), into existing legends explaining, for example, hunting or gastronomic preferences (some of my informants explained to me why a certain person does not eat pike/swan, etc.). They allow structuring the continuum of exchange procedures (Sahlins, 1999; Ssorin-Chaikov, 2012: 65); densities-thickenings form "exchange cards" (through which channels distribution takes place), exchanged resources, and other characteristics.

The collected field material shows that there are some oppositions in exchange relations (with transitional values between them), which also structure the field of exchange practices. For example, the categories of the formalized/non-formalized exchange. The first is the purchase of goods in a store (although, upon a detailed examination, it is certainly possible to identify elements of informal practices); an important aspect of the second is sharing with nature. Ways to interact with it 
as an extremely vague system in terms of building "mutual relations" lead to anthropomorphization of these processes, which is expressed in a vivid emotional experience of activity in the natural environment (in a forest, on a river), emotionality towards the natural environment itself, in preserving and reproduction of relations of balance and distribution (sacrifices to fire, water, etc.).

Other opposition groups include the legitimate/illegitimate exchange; community approved/disapproved activities. Each of these cases affects the course of exchange procedures and is associated with collective ideas and their individual experiences.

The division of the direction of exchange procedures into "internal" (intrasettlement) and "external" mentioned above also reveals some properties of the exchange in general. Thus, orientation to the "outside" is always (most often) associated with the use of the exchange values, as opposed to the internal processes, where such forms of exchange as "gift" or "barter" often occur. This is consistent with the idea of M. Sahlins that exchange practices with representatives of remote areas are of a more "market" nature, despite the fact that he considered "primitive" communities (Sahlins, 1999). Another interesting feature of the inner circle of the exchange, that is a family, is a simplified procedure and a set of actions associated with the exchange: here, the transfer of the good is carried out for granted (for example, within the framework of nimat). As if there is some static structure that does not require large mobilities, expressing the intensity of the exchange. I observed a similar situation myself, when the ethnographer's identity introduced me into a circle of close people (of course, not for everyone), where I received benefits (food, free accommodation, etc.) for my static position. However, these external statics may be associated with a more reverent attitude to human behaviour, to ethical aspects, when the benefits are compensated by the loyalty and prestige of the presenter. Thus, the exchangeable components are embedded in a stable or dynamic environment, although "stability", "static character" can hide just a different nature of dynamics.

Since the exchange always implies "thickening" or "binding", we come to the idea of complexity inherent in the practice of exchange; the very act of exchange is the "point of crystallization" of many practices, cultural and social phenomena, it becomes a kind of an "attractor" that draws in the components. "Attractor" organizes a set/ complex of practices and actions. This is not only characteristic of the exchange. On the contrary, many (almost all) elements and mechanisms of culture are characteristic of "attractiveness". But since the subject of our study is the exchange, we are talking about it. 
We also should point out another important feature related to the exchange, which reveals some "out-of-culture" exchange procedures. An interesting remark in this respect was made by Arjun Appadurai, who wrote that each exchange operation does not imply a "common cultural background." He believes that the operation, "being a social phenomenon, can bring together participants representing essentially different cultural systems," they can be "united only in the very minimum of mutual understanding... about the objects of exchange, and agree with each other only about the terms of the deal" (Appadurai, 1986: 15, quoted by Ssorin-Chaikov, 2012: 76). It is noteworthy that similar thoughts, but in a somewhat different perspective, were formulated by the Russian ethnographer V. A. Koz'min, who claimed that "in any culture the number of functionally determined elements is always greater, and in the system of cultural interaction, it is the functionality that acts as the main condition for the perception of the "alien" with subsequent adaptation and possible modification in accordance with the stereotypes of the culture of the recipient" (Koz'min, 2003: 144-145). As we see it, both in the first and in the second case, the functional, or rather, essential, communicative aspect of the exchange is highlighted. His act is fixed. This, in turn, lies in the field of arguments about the meaning and essence of the culture of M.M. Bakhtin, who wrote that culture exists on a communicative border (Bakhtin, 1986: 353-354). The idea of exchange as a border, a turning point was also expressed in the article by N. V. Ssorin-Chaikov (SsorinChaikov, 2012: 76).

We also should note such a characteristic feature of exchange as the impossibility of obsolescence as a practice, since it is an internal, inseparable property of nature and society, but its forms may change. This transitional character of exchange can be traced through the concept of a "game feeling" (Bourdieu, 1991, cited by Ssorin-Chaikov, 2012: 61), reflecting the flow of objects, practices, meanings, etc. during the exchange process. E. Leach considered the peculiarities of socio-cultural thickenings through the prism of the game action as well (Leach, 2001: 53).

The act of exchange, being a universal socio-cultural practice, acts as a general mechanism that ensures intra- and intercultural dynamics through constant redistribution. We identified 4 parameters defining the exchange: a), b) - elements participating in the exchange from different sides (in opposition); c) - conditions for the implementation of the act of exchange; d) — an interest (reason for the exchange) of agents of the operation. "A" and " $b$ " are conditioned and precondition " $d$." It seems to us that the " $\mathrm{d}$ ", in this case, includes some aspects that tend to "fall out" of the researcher's 
field of view (conditionally, the spirit of the gift "khau", according to Mauss (Mauss, 2014: 148-149)).

The same thing will not be exchanged for the same. That is, the exchange is initially associated with 1) different phenomena. Consequently, the phenomenon of exchange implies dissimilarity, heterogeneity of opposition "agents"; 2) it is associated with the need for something; with what you need to get for one reason or another. Distribution causes asymmetry that agents seek to bring to symmetry. Exchange is a meeting, a joint, a supplement and a loss. With equal exchange, something changes anyway, because the component composition becomes different. Thus, we came up with the following definition:

Exchange (ad hoc) is a combinatorial operation implemented in opposition of two or more actors (/agents) and caused by uneven distribution (including awareness/feeling of unevenness/insufficiency) of elements in opposition groups.

The implementation of the exchange operation requires a number of related operations related to the extraction, processing, etc. of the resource that is going to be exchanged. It is also important here that, in the conditions of exchange, there is always an immanently present property, which consists in the fact that in order for a certain resource to be present (to exist), certain conditions must be achieved, so that something can be understood as a resource. Therefore, it is important to study these conditions that make it possible to have a resource. And, perhaps, symbolism, complexity, "density", "binding" are connected precisely with the fact that it is necessary to constantly make some efforts, to keep in mind certain information "resourcing" (from "objectifying") a specific phenomenon. After all, it must be isolated from the environment; in essence, it is an operation of "naming" and obtaining. Then, when the exchange takes place, recombination of all connections, relations and properties that strive after the exchanged object, that is, the conditions that made this exchange possible.

\section{References}

Appadurai, A. (ed.) (1986). The Social Life of Things: Commodities in Cultural Perspectives. Cambridge, Cambridge University Press, 3-63.

Bakhtin, M.M. (1986). Estetika slovesnogo tvorchestva [Aesthetics of Verbal Art]. Moskva, Iskusstvo, $444 \mathrm{p}$.

Bourdieu, P. (1991). In Other Words: Essays towards the Reflective Society. Stanford, Stanford University Press, 219 p. 
Bourdieu, P. (2017). Sotsiologiia sotsial'nogo prostranstva [Sociology of social Space]. Sankt-Peterburg, Aleteiia, 288 p.

Callon, M. (2005). Why Virtualism Paves the Way to Political Impotence: A Reply to Daniel Miller's Critique of the Laws of the Markets. In Economic Sociology: European Electronic Newsletter, 6(2), 3-20.

Chesnov, I.V. (2001). Ot kommunikatsii k kulture, ili zachem seru Edmundu Lichu nuzhno poniat' drugogo cheloveka [From Communication to Culture, or why Sir Edmund Leach needs to understand another Person]. In Kultura i kommunikatsiia: logika vzaimosviazi simvolov. $K$ ispol'zovaniiu strukturnogo analiza $v$ sotsial'noi antropologii [Culture and Communication: Logic by which Symbols are connected]. Moskva, Vostochnaiia literatura, RAS, 125-141.

Knorozov, V.A. (1973). K voprosu o klassifikatsii signalizatsii [To the Issue of Signalling Classification]. In Osnovnye problemy afrikanistiki [The main Issues of African Studies]. Moskva, Nauka, 324-334.

Koz'min, V.A. (2003). Olenevodcheskaia kultura narodov Zapadnoi Sibiri [Reindeer Culture of the Peoples of Western Siberia]. Sankt-Peterburg, Izdatel'stvo Sankt-Peterburgskogo universiteta, 236 p.

Latour, B. (2014). Peresborka sotsial'nogo: vvedeniie v aktorno-setevuiu teoriiu [Reassembling the Social: Introduction to Actor-Network Theory]. Moskva, Izdatel'skii dom vysshei shkoly ekonomiki, 384 p.

Leach, E. (2001). Kultura i kommunikatsiia: logika vzaimosviazi simvolov. $K$ ispol'zovaniiu strukturnogo analiza v sotsial'noi antropologii [Culture and Communication: the Logic by which Symbols are connected]. Moskva, Vostochnaiia literatura, RAN, 142 p.

Malinowski, B. (2004). Izbrannoe: Dinamika Kultury [Selected Writings: The Dynamics of Culture]. Moskva, Izdatel'stvo ROSSPAN, 960 p.

Mauss, M. (2014). Obshchestva. Obmen. Lichnost'. Trudypo sotsial'noi antropologii [Societies. Exchange. Personality. Papers on Social Anthropology]. Moskva, Knizhnyi dom Universitet, $416 \mathrm{p}$.

Morris, I. (2017). Sobirateli, zemledel'tsy i iskopaemoe toplivo. Kak izmeniaiutsia chelovecheskiie tsennosti [Foragers, Farmers, and Fossil Fuels. How Human Values Evolve]. Moskva, Izdatel'stvo institute Gaidara, 488 p.

Pershits, A.I., Traide, D. (ed.) (1986). Sotsial'no-ekonomicheskie otnosheniia $i$ sotsionormativnaia kul'tura (Svod etnograficheskikh poniatii $i$ terminov) [SocioEconomic Relations and Socio-Regulatory Culture (Code of ethnographic Concepts and Terms)]. Moskva, Nauka, 239 p. 
Sahlins, M. (1999). Ekomonika kamennogo veka [Stone Age Economic]. Moscow, OGI, 296 p.

Sirina, A.A. (2011). Nimat: obychai delezha u severnykh tungusov [Nimat: Divide Custom in the Northern Tungus]. In Antropologiia sotsial'nykh peremen. Issledovaniia po sotsial'no-kul'turnoi antropologii [Anthropology of social Change. Social and cultural Anthropology Research]. Moskva, ROSSPEN, 301-320.

Ssorin-Chaikov, N.V. (2012). Medvezh'ia shkura i makarony: o sotsial'noi zhizni veshchei $\mathrm{v}$ sibirskom sovkhoze i performativnosti razlichii dara i obmena [Bear Skin and Macaroni: on the social Life of Things in the Siberian State Farm and the Performativity of the Gift and Exchange Differences]. In Ekonomicheskaia sotsiologiia [Economic Sociology]. Moskva, Izdatel'skii dom vysshei shkoly ekonomiki, 13(2), 59-81.

Urry, J.R. (2000). Sociology beyond Societies. London — New-York, Routledge, $255 \mathrm{p}$.

\title{
Ресурсы и обмен в Северной части Республики Саха (Якутия)
}

\author{
Н.С. Гончаров \\ Музей антропологии и этнографии \\ им. Петра Великого РАН (Кунсткамера) \\ Россия, 199034, Санкт-Петербург, \\ Университетская наб., 3
}

В статье рассмотрены параметры обмена ресурсами в поселке на р. Лена в Северной части Якутии. Основная иель работы - это прояснение феномена обмена через исследование особенностей выстраивания сочиально-культурного пространства посредством обменных практик. В качестве предмета исследования выступает феномен обмена, локализованный в конкретном контексте его функиионирования. Работа основана на материалах, собранных автором в ходе экспедиции 2018 г. В первой части статьи определяется проблема исследования, кратко описываются основные теоретические разработки, применяемые в статье либо оказавшие влияние на характер рефлексии автора по поводу данного материала. Далее следует описание социально-культурных компонентов, оформляющих обменные практики; произведено «рассеивание» общего контекста поселка на отдельнье группы элементов, объединенные (лишь потенцииально) функциональной связью с феноменом обмена. Также рассмотрены примеры «контекстов», складываемые из этих элементов и отражающие их различные связки: в сфере промыслов, торговли, кормления духов, народных праздников и др. В заключительной части формулируются 
основные взгляды и выводы автора по поводу исследуемой проблемы: соичальнокультурное поле обменов представляется континуумом отношений, материальных (живых и неживых) объектов, их поведением, свойствами и пр., что требует особого «инструмента» для работы с ним. Такими «инструментами», по мнению автора, выступают концепты «сгущения», «уплотнения», «развязывания» и m. п., поскольку в непрерывном поле отношений обмена они позволяют производить фиксации ичентров «сгущений» определенных параметров, указывающих на специифику обменных процедур. Сделан вывод о «внекультурном» актуальном свойстве акта коммуникации в форме обмена, обозначен его связывающий потенщиал. Через структурный анализ обмена в общем виде сделан вывод о ресурсной асимметрии, провочирующей обмен, дано определение обмену. Выводы могут быть применены к анализу энергетических потоков в социокультурной среде.

Ключевые слова: обмен, сочиально-культурное пространство, сгущение, рыболовство, промыслы, контекст, торговля, континуум, аттракторность.

Работа выполнена за счет гранта Российского научного фонда (проект № 18-1800309).

Научная специальность: 07.00.07 - этнография, этнология и антропология. 